aries are mathematical and artificial : with one or two exceptions they have no geographical meaning. The early settlements around the island-continent were separated by long stretches of inhospitable coast and still more difficult interior. From these various centres the human settlement developed on old-world lines. This is expressed in the various state railway systems, each planned without reference to those of adjoining states.

The geographical and economic unity of the island was overlooked until a much later date, but the commonwealth feeling or spirit is now making rapid headway and is reflected in the new and newly planned railway lines. These lines are projected to bind together and not to separate the varjous states. All major Australian railway schemes are essentially commonwealth propositions in that they involve the interests of more than one state. A sketch map was shown to indicate the economic areas, independent of political divisions, which may be regarded as the hinterlands of different stretches of sea coast. On this map it is possible to forecast, with tolerable certainty, the main outlines of the completed Australian railway system. Briefly, this entails an outer ring of which the elements already exist; an inner circle; fragments of a radial system cutting across both circles and joining hinterlands with their appropriate ports; certain overland lines from north to south and east to west. These systems when fully built will unify the continent and overrule the artificiality of the original states.

\section{Structure of Greenland.}

WE have recently received, though the work is dated 1920, volume 53 of the "Neue Denkschriften der Schweizerischen. Naturforschenden Gesellschaft," 1 containing an account of the Swiss trans-Greenland Expedition of I9I2-I3. Between southern Greenland at about lat. $64^{\circ}$, where the country was crossed by Nansen in I888, and Peary's routes of I892-95 through $80^{\circ} \mathrm{N}$., the interior of Greenland remained unknown for an interval of more than rooo miles. In order to determine the structure along one line through this gap a Swiss expedition under Prof. de Quervain in I9I2 traversed Greenland from the western coast in lat. $69^{\circ} 46^{\prime}$ opposite Disko to the eastern coast in lat. $66^{\circ}$. The journey on the inland ice was begun on June 20 . The summit of the ice-cap was crossed on July 8 , and its eastern margin was reached on July $2 I$. The party, with dog-drawn sledges, averaged 22 kilometres a day. Meanwhile the western party under Prof. Mercanton investigated the open country on the western edge of the ice-cap to the east of Disko Island.

The new traverse of Greenland confirms the general accuracy of Nansen's profile, though, as he crossed the country where the ice-cap is narrower but rises to a greater height, his gradients were steeper than those found by the Swiss party. Doubt is thrown as to the distance inland reached by von Nordenskjöld in 1883 . The expedition, however, supports his view that cryoconite consists in part of meteoritic material. Nordenskjöld's conclusion has generally been rejected and the material explained as dust blown on to the ice from the nearest rocks. Part of the cryoconite collected by the Swiss expedition is regarded as derived from local diorite, but it contains spherules of magnetite which Prof. Mercanton regards as possibly of extra-terrestrial origin. In this view he supports the conclusions of Wulfing and of Swinne 1 "Neue Denkschriften der Schweizerischen Naturforschenden GesellNaturelles) Band 53. Pp. xx $+402+54$. (Basel, Genf und Lyon: Georg und Co., 1920.)

$$
\text { NO. } 2826 \text {, vOL. I I } 27
$$

(I9r9). In the absence, however, of proved nickel the meteoritic origin of the magnetite may still be regarded as open to doubt.

The western party made careful measurements of the ice movements, and found it to vary from less than a centimetre a day on the ice front to $2 \frac{1}{3}$ metres. It is shown that the bare land in west-central Greenland was once covered by the ice-sheet, and Prof. Mercanton supports the view that, with the exception of some of the high southern mountains, the whole of Greenland was once buried under an ice-cap. His account and photographs show the powerful disruptive effect of frost on bare rocks in the neighbourhood of ice. The larger part of the volume is occupied by the meteorological observations and results, including the records of some pilot-balloons.

The last chapter describes the collection of Eskimo skulls, and its author, Dr. Hoessly, rejects the view that the Eskimo reached Greenland from Europe across the Faroes and Iceland; he regards the Eskimo as the most primitive section of the Mongolian race. The volume is well illustrated by four plates of maps and sections, nine plates, and numerous figures in the text.

\section{Building Materials made of Waste Materials.}

By Prof. A. P. LAurie.

WE have in Great Britain large accumulations of blast furnace slag, of cinders, and clinker, and in the neighbourhood of Edinburgh of burnt shale, the residue from the stills of the oil industry. There are three ways in which these materials can be utilised-for the production of bricks, for the production of cement, and as aggregate mixed with Portland cement or plaster of Paris. The general method adopted for the production of bricks is known as the sand lime process. Briefly, this process consists of mixing the aggregate with a certain proportion of lime and water, squeezing it into a brick under a pressure of some two hundred tons to the area of the brick and then steaming under high pressure or in open steaming chambers. Bricks are now being manufactured by this process from sand, blast furnace slag, granulated by being run while hot into water, clinker, town refuse, slate dust, and burnt shale.

Cement is being manufactured by two of the Scottish steel companies from blast furnace slag granulated, mixed with lime, and then raised to a high temperature so as to form a clinker in the same way as ordinary Portland cement was manufactured. This cement, known in Germany as iron cement, can be sold in this condition, or can be finally ground with a mixture of a certain proportion of raw blast furnace slag.

The uses of these materials as an aggregate opens the question of how far it is possible to reduce the content of Portland cement and, at the same time, get sufficient strength for building purposes. The objection to the usual building slab made of cement is that, in order to be able to remove it from the machine as soon as made, the content of water has to be kept low and, consequently, the crushing strength of the finished slab is also low. Two interesting methods of getting over this difficulty are the Crozite method, in which the cement bricks were sliced off from the bottom of a column of cement and aggregate, and the method used by the Triangular Construction Company, in which a heavy compression is put upon the bottom and top of the slab at the

1 Substance of a lecture delivered at the Royal Academy of Arts, London, on Wednesday, November 21. 
moment of completion. It has been possible in the case of the slabs made by the Triangular Construction Company to reduce the amount of cement to one to twelve of aggregate, and the manufacture of cement bricks by the Crozite process is being carried on in a large scale in America.

Many waste products such as sawdust, disintegrated wood, and ordinary cheap aggregates such as clinker can be utilised in slabs made from plaster of Paris. There are large and easily available deposits of gypsum in Great Britain, but the industry has never been developed on the enormous scale found in America, where all kinds of materials required by the builder have been turned out made from plaster of Paris as the cement.

\section{University and Educational Intelligence.}

THE University Bulletin issued by the Association of University Teachers has hitherto been confined mainly to a record of the activities of the Association, which have been concerned largely with questions of remuneration and other conditions of tenure of university posts. In the November issue an effort is made to widen its circle of readers. Lord Gorell contributes an article dealing with three subjects: (I) expected developments of the functions of the Teachers' Registration Council with the view of the establishment of teaching as one of the unified learned professions; (2) the financial needs of universities; and (3) the projected Imperial Education Bureau. Prof. Arthur Thomson's thoughtful and arresting essay on the essentials of education deserves a wider circulation thar the Bulletin can hope to give it. Here is a biologist dealing with the ignorance of young Scotland as faithfully as Prof. Burnet in his Romanes lecture dealt with the same subject from the point of view of the humanist. Over the familiar initials M. E. S. appears a plea for large capital grants to universities as recommended by the Royal Commission of I870 on Scientific Instruction and the Advancement of Science. Prof. Sandbach tells of a committee having been appointed by the A.U.T. to consider and report on the subject of co-operation between libraries, possibly on the lines of the German central information bureau and general card catalogue, for the benefit of research workers in Great Britain and Ireland. There is also a contribution from Melbourne on the perils of inbreeding and localism in universities in the Overseas Dominions.

TrE North of Scotland and the Edinburgh and East of Scotland Colleges of Agriculture append to their calendars for $\mathrm{I}_{923-24}$ lists of appointments gained by their students. They illustrate the Scottish propensity, referred to in Mr. Rudyard Kipling's recent rectorial address, for " raiding the world in all departments of life--and government." The lists include posts in England (53), Canada, the United States, South America, the West Indies, Australia, New Zealand, South, West, East, and Central Africa, the Sudan, Egypt, Cyprus, Hungary, India, Burma, Ceylon, Straits Settlements, Malay States, Java, Sumatra, Borneo, Fiji, and Hawaii: only 6o out of the 280 were in Scotland. The director of studies of the North of Scotland College reports that in 1922-23 a record number of students (27) obtained the degree in agriculture. Both colleges do a large amount of " county extension" work in addition to the instruction and research carried on at their headquarters and at college and experimental stations. The northern college report records 67,096 attendances and 2929 classes and lecture meetings and $\mathrm{II}, 84^{\circ}$ visits to farms and crofts for instruction and advice. A scheme of rural science to be taught in conjunction with school gardening was introduced into several schools and proved efficacious " in creating an interest in school gardening which is lacking at present."

RHODES Scholars in residence at Oxford in I922-23 numbered 273, namely, I 25 from the British Empire and 148 from the United States. Of these, 57 were taking natural science and medicine, ro economics, and 6 mathematics. Sixty-eight Rhodes scholars were successful in the final honour schools examinations, namely, first class I4 (United States 8, Canada 2, Australia 2, New Zealand I, South Africa I); second class 31 (United States 16 , others 15 ); third and fourth classes 23 (United States II, others I2). The $\mathrm{Ph} . \mathrm{D}$. degree was awarded to 7 (all from the United States), the B.Sc. or B.Litt. to 17 , and the B.C.L. to 18 , Among other academic distinctions obtained by Rhodes scholars may be mentioned the Christopher Welch scholarship in biology and the James Hall Foundation essay prize, / both won by Americans, the Francis Gotch memorial prize won by a scholar from New Brunswick, the David Syme research prize (Melbourne) won by a scholar from Victoria, the Bourse des CEuvres françaises à l'étranger (tenable for one year in a university in France) awarded to a New South Wales scholar, two demonstratorships and a tutorial fellowship at Oxford awarded to two Australians and a South African, and a Rockefeller Medical research fellowship, tenable in the United States, to which an Australian scholar was elected. In athletics distinctions were won by II scholars from the United States, ro from Australasia, 6 from Canada, and 4 from South Africa.

A NotABLE citizen of Bolton, Lancashire, Mr. J. P. Thomasson, made known to the School Board of the Borough in 1876 his intention to allot the sum of $750 l$. annually for a period of ten years, in order to assist scholars from the elementary schools to proceed to higher schools before becoming pupil teachers. His purpose was to secure a body of teachers in elementary schools efficiently educated and properly trained for their duties. The School Board felt that the full benefit to be derived from the scholarships would not be realised if they were restricted to those entering upon the profession of teacher, and $\mathrm{Mr}$. Thomasson consented to enlarge the scope of the scheme so as to encourage pupils from the elementary schools to continue their education at higher schools and to encourage suitable pupils to become teachers. The scheme provided fees, books, railway fares, and a grant towards maintenance. Mr. Thomasson died in 1904, and Mrs. Thomasson intimated her willingness to continue the benefaction for a further period. Meantime the School Board ceased to act and the Town Council became the Education Authority. The scheme was enlarged in its scope, and provision was made for scholarships for boys and girls between 16 and 17 years of age who had been in attendance at secondary schools in Bolton to continue their education in such schools, for leaving scholarships of the annual value of $15 \mathrm{ol}$. tenable for three years at a university and for a postgraduate scholarship at a foreign university of the annual value of $200 \mathrm{l}$. tenable for two years. The scheme has now come to an end. During the 46 years of its existence under varying conditions there have been awarded 122 major exhibitions, 427 minor scholarships, 36 scholarships in respect of continued education at secondary schools, 18 university scholarships, and one post-graduate scholarship. The total sum received from Mr. and Mrs. Thomasson amounts to 26,4387 , and the examination expenses, etc., to only I $7 \mathrm{r} 8 l$. during the whole period, testifying to the fact that the scheme has been most economically administered. 